\title{
ORI finds Imanishi-Kari guilty of misconduct, proposes 10-year ban
}

Washington. A long-awaited report released in Washington this week finds Theresa Imanishi-Kari, co-author with the Nobel laureate David Baltimore of an controversial immunology paper, to be guilty of 19 charges of scientific misconduct. It recommends that she be barred from receiving federal research funds for 10 years.

The report was issued by the Office of Research Integrity (ORI), part of the Department of Health and Human Services. It is a culmination of nine years of extraordinary investigations which have involved the Congress, forensic experts from the Secret Service, and investigators from the National Institutes of Health's former Office of Scientific Integrity.

The report, which includes about 200 pages of forensic evidence, statistical analysis and scientific discussion, took three and a half years to complete. This time span has itself been criticized. "It is an excellent report," says one congressional source. "But it is unconscionable that it took so long."

But even now the matter is not yet closed. Imanishi-Kari has filed an appeal, and has told Tuft's University in Massachusetts, where she now works, that the ORI's findings are "totally unfounded".

David Baltimore, professor of molecular biology and immunology at the Massachusetts Institute of Technology - who re- signed as president of Rockefeller University in New York following criticism from colleagues of his defence of Imanishi-Kari - told Nature on Monday that "to my knowledge, she never did anything wrong". He added: "I believe the ORI report is totally wrong in accusing her of misconduct."

But Lyle Bivens, director of the ORI, said after a moment's reflection that she found Baltimore's comment "baffling", adding: "I'll stand by the report."

The specific conclusions of the report are that Imanishi-Kari fabricated and falsified critical parts of her published results, and that she compounded this by denying the misconduct and fabricating data that "she claimed supported her initial findings". The report also concludes that she "further compounded the fabrications and falsifications by referencing or reporting them in grant applications submitted to the National Institute's of Health".

Imanishi-Kari's research group had been investigating how a gene from a B-cell of one strain of mice would affect the type of antibodies produced by the immune system of another strain. The work constitutes one approach to understanding the regulation of the immune system, and could in the long run have implications for understanding how to confer resistance to disease.

The controversy started in 1986 when

\section{UK 'protects' health research funds}

London. Virginia Bottomley, Britain's health secretary, last week announced that the government had agreed to allocate an additional $£ 40$ million ( $\$ 62$ million) to university medical schools to help cover the costs of research in teaching hospitals.

Bottomley's decision is in line with her earlier endorsement of proposals made in a report prepared by a

team under

Anthony Culyer, professor of medical economics at the University of York, that health department funding for research should be channelled into a single, identifiable stream.

In making the announcement, Bottomley said that the additional money being provided directly to the medical schools will allow work to be speeded up within the National Health Service's research and development programme in "innovative and evidence-based health care."

But health department officials admit that the extra support for research does not represent 'new money'. An equivalent amount will be taken away from that which is provided to local authorities and other health 'purchasers' for buying the services of teaching hospitals, which will be expected to reduce the prices that they charge to health care purchasers accordingly.

While acknowledging the government's plan that this should lead to a more level playing field for the providers of health care - i.e. by bringing the costs charged by teaching and non-teaching hospitals closer in line - many medical schools fear they could lose out.

"The extra $£ 40$ million is a welcome contribution," says Michael Powell of the Committee of Vice-Chancellors and Principals, the body which represents university medical schools in their negotiations with government. "But universities would like to see it go much further than that."
Margot O'Toole, a post-doctoral research fellow in Imanishi-Kari's laboratory at MIT, noticed that data in a laboratory notebook did not support those that had been published. She claims that she was also put under pressure to report her own data in a misleading fashion. "From the beginning I just wanted a correction," says O'Toole. "I didn't want anyone debarred."

O'Toole discussed the discrepancies with senior scientists and subsequently with officials at MIT and Tufts. Both universities reviewed the paper, MIT because ImanishiKari worked there, and Tufts because she was a candidate for a post at the university.

MIT found no evidence of deliberate falsification or fabrication, and Tufts agreed that O'Toole had identified an error but that it was not flagrant. (The ORI is now undertaking an investigation into how the two universities handled O'Toole's allegations)

Shortly afterwards, the National Institutes of Health put together a panel to investigate the affair. This found "significant errors of misstatement or omission", but concluded that there was no evidence of fraud or conscious manipulation.

At about the same time, however, the House subcommittee on oversight and investigation, chaired by John Dingell (Democrat-Michigan), subpoenaed the original data, and opened its own investigation. In addition, according to the ORI report, the NIH discovered that Imanishi-Kari's notebooks "had not been compiled contemporaneously with the conduct of the reported experiment".

The NIH reopened its investigation, and its Office of Scientific Integrity completed a draft report in March 1991, which found scientific misconduct based on falsification and fabrication. The US Attorney in Maryland considered a criminal prosecution. When no prosecution resulted, the newly formed ORI, which had replaced the Office of Scientific Integrity, took up the case. Its findings are similar to, but more extensive than, those of the OSI.

O'Toole, who for a long time was coldshouldered in academic circles, is now a research scientist working at the biotechnology company GI in Boston. "It is so hard to bring evidence of scientific misconduct to light," she says. "Even if there is incontrovertible evidence, there are monumental hurdles."

O'Toole is one of four whistleblowers that the Commission on Research Integrity has asked to testify at hearings being held this week. "My main point will be about the importance of the integrity of data," she says.

Helen Gavaghan 